\title{
Flea Beetles of the Genus Altica, Altica spp. (Insecta: Coleoptera: Chrysomelidae) ${ }^{1}$
}

\author{
Eleanor F. Phillips. and Jennifer L. Gillett-Kaufman²
}

\section{Introduction}

Flea beetles are in the largest subfamily (Alticinae) of the family Chrysomelidae, or leaf beetles (Furth 1988). The name Altica is derived from the Greek word haltikos, which translates to good jumper. Although this group of insects are named flea beetles, this is not because the form of the body resembles fleas, but rather because they have strong hind legs allowing them to jump long distances like true fleas (Siphonaptera). Their great jumping skills are thought to have evolved as a mechanism to escape from predators.

In the southeastern U.S.A, Altica flea beetles can be found in many different habitats depending on the species and its host plants, in landscapes or nurseries Altica litigata Fall can be found damaging crape myrtles, Lagerstroemia spp. (Lythraceae) (Jenkins et al. 2009, Renkema et al. 2014). Other common flea beetle species of this genus found in the southeastern U.S.A. of economic importance are Altica torquata LeConte, which is commonly found on grapevines (Vitis spp.) (Vitaceae), and Altica sylvia Malloch, which is found on blueberries (Vaccinium spp.) (Ericaceae).

Although these species may become pests because they feed on economically important plants, some flea beetles in this genus may be considered beneficial because of their significant use for bio-control of weeds (Wan and Harris 1997). Damage to vegetation, and life history patterns of common flea beetles, are very similar among Altica species

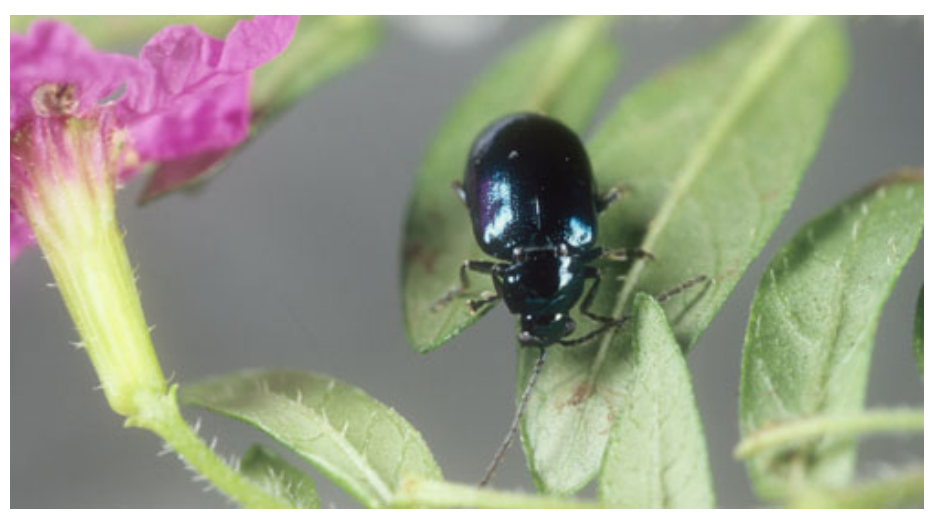

Figure 1. An Altica sp. flea beetle feeding on Cuphea hyssopifolia (false heather) in Gainesville, Florida.

Credits: Lyle J. Buss, UF/IFAS

with the major differences being host plant preference and control recommendations.

\section{Distribution}

Altica spp. have a worldwide distribution (Kostantinov and Vandenberg 1996). There have been 72 species in the genus Altica reported in America north of Mexico alone (Riley et al. 2003). Some of the more commonly encountered species and their host plants, in addition to the aforementioned species, are:

- Altica chalybea Illiger, grapes

- Altica corni Woods, dogwood

1. This document is EENY-721, one of a series of the Entomology and Nematology Department, UF/IFAS Extension. Original publication date January 2019. Visit the EDIS website at https://edis.ifas.ufl.edu for the currently supported version of this publication. This document is also available on the Featured Creatures website at http://entnemdept.ifas.ufl.edu/creatures/.

2. Eleanor F. Phillips, and Jennifer L. Gillett-Kaufman; Entomology and Nematology dept., UF/IFAS Extension, Gainesville, FL 32611

The Institute of Food and Agricultural Sciences (IFAS) is an Equal Opportunity Institution authorized to provide research, educational information and other services

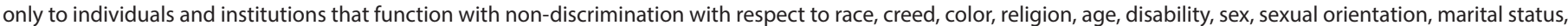

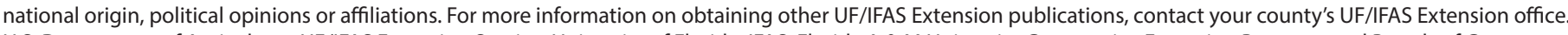
U.S. Department of Agriculture, UF/IFAS Extension Service, University of Florida, IFAS, Florida A \& M University Cooperative Extension Program, and Boards of County Commissioners Cooperating. Nick T. Place, dean for UF/IFAS Extension. 
- Altica foliaceae LeConte, apple

- Altica ignita Illiger, strawberry

- Altica litigata Fall, crape myrtle

- Altica sylvia Malloch, blueberry

\section{Description}

Most Altica flea beetles have hard outer wings called elytra that are metallic blue to green in color that protect similarly colored metallic bodies that reflect purple and bronze colors, and elongate oval in shape (Pettis and Braman 2007, LeSage 1995). Altica flea beetles are generally indistinguishable based on external morphological differences, so to ensure the correct identification of an Altica sp. beetle, molecular analysis of DNA markers is the most reliable way to determine the exact species of Altica (Ruhl et al. 2010), although examination of internal genitalia or identification based on host plant association is sometimes used.

The hind legs of the flea beetle are enlarged (Pettis and Braman 2007). Altica flea beetles are between 3-9 mm, and females are typically larger than males (LeSage 2000). All Altica spp. have round eyes (LeSage 1995). Altica flea beetle antennae have 11 segments and are filiform (threadlike) in shape (Kostantinov and Vandenberg 1996). The biology of less than $10 \%$ of Altica flea beetle species in North America is documented, with research focusing only on the most economically important species (LeSage 1995). Here we discuss mostly Altica litigata because its biology has been studied.

\section{Biology}

Eggs: Altica litigata eggs are oval and 1 to $2 \mathrm{~mm}$ in length. Eggs are laid on the upper and lower surface of the leaves in clutches of one to 15 (LeSage 1995) (Figure 2).

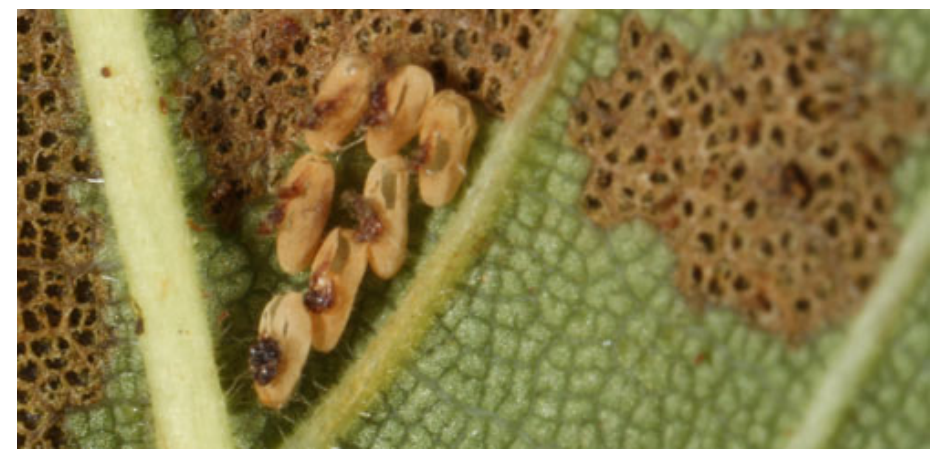

Figure 2. Hatched eggs of an Altica sp. flea beetle on the underside of an elm leaf in Gainesville,

Credits: Lyle J. Buss, UF/IFAS
Larvae: The larvae emerge 5 to 8 days after oviposition (egg laying) (Konstantinov and Vandenberg 1996). The larvae hatch and feed on the leaves of their host plants. The larvae appear dark brown to black, and average $5.2 \mathrm{~mm}(0.2$ inches) in length. The larvae have 10 body segments, with three pairs of small legs near the head (Lee and Shim 2003). The larvae experience three larval instars, or immature life stages (LeSage 1995). Smaller larvae can be found on the undersides of leaves, and larger larvae can be found consuming leaves and limbs of host plants (LeSage 1995). Many Altica species are gregarious, or found in clusters, when feeding (LeSage 1995) (Figure 3). Eventually, the larvae move down from their host plant onto the ground to pupate in the soil or leaf litter (Pettis et al. 2004).

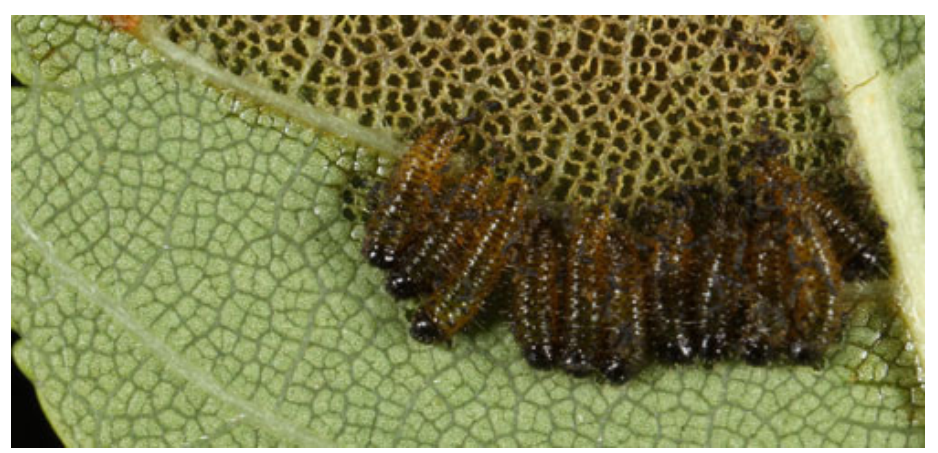

Figure 3. Larvae of Altica sp. feeding gregariously on the underside of an elm leaf.

Credits: Lyle J. Buss, UF/IFAS

Pupae: Pupal cases are formed using mucus produced in the maxillary glands. Pupation generally occurs in the top 1 to $2 \mathrm{~cm}$ of the soil. Overwintering occurs in this stage (LeSage 1995).

Adults: Adult flea beetles emerge from their pupal cases in the spring and feed on the foliage of their host plant (Lee and Shim 2003) (Figure 4). Males are usually smaller than females (LeSage 1995). The flea beetles may produce one to three generations a year, depending on location (Chappell et al. 2012). In more northern latitudes, there is typically one generation of Altica per year, but in the southern U.S.A. there can be two to three generations per year (LeSage 1995). 


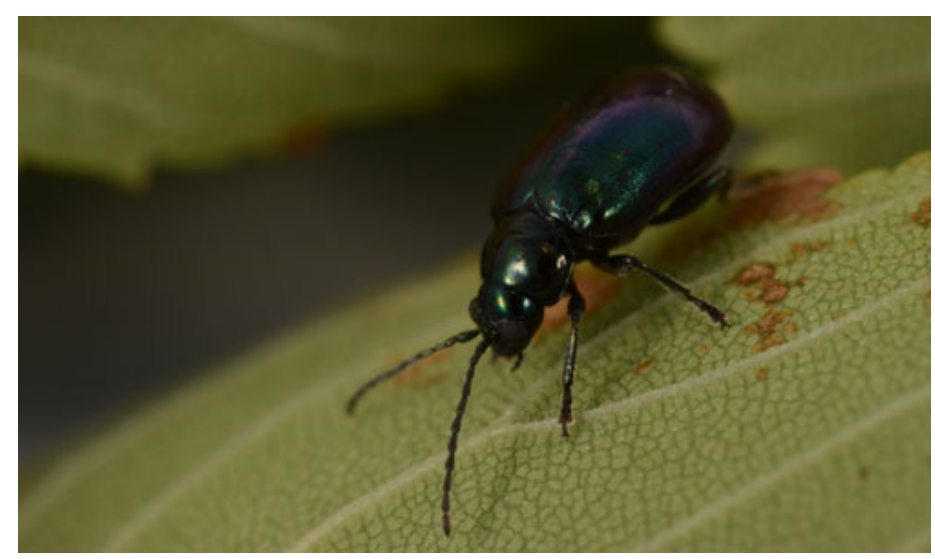

Figure 4. Adult Altica sp. feeding on an elm leaf in Gainesville, Florida. Credits: Lyle J. Buss, UF/IFAS

\section{Host Plants}

Altica flea beetles feed on plants as both larvae and adults, and may damage economically important ornamental plants. Many flea beetle species in the genus Altica have a relatively broad host range, feeding on plant species in one or two families. The preferred family of host plants for Altica litigata is Onagraceae, which includes popular ornamental plants such as evening primrose (Oenothera species), Fuschia species, wavyleaf beeblossom (Guara sinuara), marsh seedbox (Ludwigia palustris), many-fruit primrose (Ludwigia polycarpa), and common eveningprimrose (Oenothera biennis) (Clark et al. 2004). Weedy plants such as willowherb (Epilobium species) may also be host plants for Altica litigata (Pettis et al. 2004).

Altica litigata has been found on numerous plants outside the family Onagraceae, and these reports may prove a result of the notoriously difficult sight identification of the genus Altica, or may be minor occurrences. Altica litigata is known to occasionally switch from their host plant to crape myrtles (family Lythraceae), particularly in nurseries (Pettis et al. 2004). In the southeastern U.S.A., adult Altica litigata have been reported to cause damage to crape myrtle., however, a complete life cycle of the flea beetle has not been observed on crape myrtle, suggesting that the Altica found on the crapemyrtle may have moved to the plant after growth and development occurred on its primary host plant (Jenkins et al. 2009).

\section{Management}

Adult flea beetles in the genus Altica are herbivorous pests that are very difficult to differentiate with the naked eye. Even when magnified with a microscope, the morphology of different Altica beetle species can be indistinguishable. For this reason, many flea beetles in this genus are differentiated by their host plant preference (Jenkins et al. 2009,
Pettis et al. 2004). The presence of adult Altica flea beetle damage can be seen initially as small holes in the leaves, and if the infestation is heavy, they can completely defoliate young branches (Chappell et al. 2012).

The removal of potential weed hosts of Altica litigata from areas close to ornamental hosts may prevent flea beetle infestation of crapemyrtle. Scouting for Altica litigata on crape myrtle in early spring will help prevent a heavy infestation especially if the insects are detected and controlled early. Altica resistant cultivars of crapemyrtle have been identified, and planting these cultivars will decrease the likelihood of heavy flea beetle infestation. Crape myrtle cultivars resistant to Altica species include 'Acoma', 'Lipan', 'Muskogee,' 'Natchez, 'Osage, 'Tonto', and 'Tuscarora' (Chappell et al. 2012). Parasitoids from the family Tachinidae (Diptera) have been identified in adult Altica. Parasitoids in the family Braconidae (Hymenoptera) have been identified in both larval and adult Altica. The fungus Spirotrichum has been observed to reduce populations of Altica as well, but neither parasitoids nor fungal pathogens have been studied for effectiveness as biological control agents (LeSage 1995).

\section{Selected References}

Chappell MR, Braman SK, Williams-Woodward J, Knox G. 2012. Optimizing plant health and pest management of Lagerstroemia spp. in commercial production and landscape situations in the southeastern United States: A review. Journal of Environmental Horticulture 30: 161-172.

Clark SM, LeDoux DG, Seeno TN, Riley EG, Gilbert AJ, Sullivan JM. 2004. Host Plants of Leaf Beetle Species Occurring in the United States and Canada. The Coleopterists Society, Special Publication No. 2. Sacramento, California. p. 15.

Furth DG. 1988. The jumping apparatus of flea beetles (Alticinae) - The metafemoral spring, pp. 285-297 In Biology of Chrysomelidae, Jolivet P, Petitpierre E, Hsiao TH (eds). Kluwer Academic Publishers Dordrecht, The Netherlands.

Jenkins TM, Braman SK, Chen Z, Eaton TD, Pettis GV, Boyd DW. 2009. Insights into flea beetle (Coleoptera: Chrysomelidae: Galerucinae) host specificity from concordant mitochondrial and nuclear DNA phylogenies. Annals of the Entomological Society of America 102: 386-395.

Konstantinov AS, Vandenberg NJ. 1996. Handbook of Palearctic flea beetles (Coleoptera: Chrysomelidae: Alticinae), 
pp. 237-440 In Contributions on Entomology, International. Associated Publishers. Gainesville, Florida.

Lee JE, Shim JH. 2003. Systematic study of larvae of North American Alticinae (Coleoptera: Chrysomelidae) by larval characters: Part I. Genus Altica from North America. The Korean Journal of Systematic Zoology 19: 19-31.

LeSage L. 1995. Revision of the costate species of Altica Müller of North America north of Mexico (Coleoptera: Chrysomelidae). The Canadian Entomologist 127: 295-441.

LeSage L. 2000. On the type series of Altica chalybea (Coleoptera: Chrysomelidae). Entomological News 111: 233-237.

Pettis GV, Braman SK. 2007. Effect of temperature and host plant on survival and development of Altica litigata Fall. Journal of Entomological Science 42: 66-73.

Pettis GV, Boyd Jr. DW, Braman SK, Pounders C. 2004. Potential resistance of crape myrtle cultivars to flea beetle (Coleoptera: Chrysomelidae) and Japanese beetle (Coleoptera: Scarabaeidae) damage. Journal of Economic Entomology 97: 981-992.

Renkema JM, Cutler GC, Rutherford KR. 2014. Molecular analysis reveals lowbush blueberry pest predation rates depend on ground beetle (Coleoptera: Carabidae) species and pest density. BioControl 59: 749-760. DOI: https://doi. org/10.1007/s10526-014-9614-7.

Riley EG, Clark SM, Seeno TN. Catalog of Leaf Beetles of America North of Mexico (Coleoptera: Megalopodidae, Orsodacnidae and Chrysomelidae, excluding Bruchinae). Coleopterists Society. Special Publication No. 1 Sacramento, California. pp. 104-109.

Ruhl MW, Wolf M, Jenkins TM. 2009. Compensatory base changes illuminate morphologically difficult taxonomy. Molecular Phylogenetics and Evolution 54: 664-669.

Wan FH, Harris P. 1997. Use of risk analysis for screening weed biocontrol agents: Altica carduorom Guer. (Coleoptera: Chrysomelidae) from China as a biocontrol agent of Cirsium arvense (L.) Scop. in North America. Biocontrol Science and Technology 7: 299-308. 